Stetson University held an institute on Southeast Asia February 6-8 with three guest lecturers participating in the lectures and discussions. The participants were Professor William C. Johnstone of the Johns Hopkins School of Advanced International Studies, Professor Lucian Pye of MIT, and Dr. Nguyen Phu Duc of the Vietnamese Embassy.

The institute was part of a cooperative venture by four mid-Florida colleges and was made possible by a grant from the Danforth Foundation. Comparable institutes were held at the same time on the other three campuses (Rollins, Florida Southern, Florida Presbyterian). Next year the theme of the Institute will be "China and India in Crisis."

The thirty-ninth session of the Institute of World Affairs was held December 2-5, 1962, at the Huntington-Sheraton Hotel in Pasadena under the direction of J. William Robinson of Whittier College.

Professor Robinson chose the theme "Commitment to Freedom" for the thirty-ninth institute, dealing, in his words, with "The Positive Side of the American Record in Foreign Policy." Daily programs had to do with National Goals and the World Around Us, Economic and Social Policy, Policy and Progress in Science, Policy in International Cooperation, and Decisions and Methods.

Chairmen of the daily programs included Chancellor von KleinSmid, Vice President Carl M. Franklin of USC, and Arthur C. Turner of the University of California at Riverside. Evening speakers were Ambassador John M. Allison, now at the University of Hawaii, Sergio Bath of the Brazilian Embassy, General William H. Draper, Assistant Secretary of State Edwin M. Martin, Hans J. Morgenthau, Lt. Col. John A. Powers, General Thomas D. White, and Paul Tillich.

At the thirty-ninth institute papers were read by Willard A. Beling, USC; Ben G. Burnett, Whittier College; Robert S. Gibbs, Boston University; Ronald Hilton, Stanford; Nobutaka Ike, Stanford; President E. Wilson Lyon, Pomona College; Charles A. McClelland, San Francisco State College; Helen Dwight Reid, George Washington University; Franz B. Schick, University of Utah; Dean John M. Swarthout, Portland State College; James T. Watkins, IV, Stanford; and C. S. Whitaker, Jr., University of California at Los Angeles.

The Institute of World Affairs was founded by Chancellor Rufus B. von KleinSmid of the University of Southern California in association with a group of scholars representing the major institutions of the West. Professor James T. Watkins, IV of Stanford University, the director of the fortieth session, which will be held at the HuntingtonSheraton Hotel December 1-4, 1963, has selected "The Grand Design" as the theme of the meeting.

Correspondence with reference to the $1963 \mathrm{In}$ stitute, including suggestions as to interested participants, should be addressed to Paul E. Hadley of the University of Southern California.

The Iowa Conference of Political Scientists held its 1963 annual meeting at Loras College on April 6.

During the morning session Paul Smith of Grinnell College delivered a paper on "Community Power and Influence in East-Central Iowa." Serving as discussants were Donald E. Boles of Iowa State University, Robert Horgan of Clarke College, John C. Norton of St. Ambrose College and Russell Ross of the State University of Iowa.

The afternoon session was devoted to a debate between C. Edwin Gilmour of Grinnell College and State Senator David O. Shaff on "Party Responsibility and Reapportionment in Iowa."

Newly elected officers include: president, Donald E. Boles, Iowa State University; secretary-treasurer, John P. Dorweiler, Loras College; members of the executive committee, Robert Horgan, Clarke College; J. B. Board, Jr., Cornell; Paul Smith, Grinnell; M. W. McMahon, St. Ambrose; N. L. Fadness, Luther College; Robert Boynton, State University of Iowa; Erma Plaehn, State College of Iowa; Charles Clarke, Upper Iowa University.

The 20th Congress of the International Institute of Sociology, originally planned for September, 1962, has now been scheduled to meet September 5-11, 1963 in Cordoba, Argentina, under the auspices of the National University there. Registration fees (\$5) and correspondence concerning participation should be addressed to Professor Alfredo Poviña, Trejo 241, Córdoba, Argentina.

\title{
REPORT OF THE STATE DEPARTMENT ADVISORY COMMITTEE ON FOREIGN RELATIONS
}

The Committee met on November 2 and 3, 1962 , and examined in detail the problems connected with the series. The gist of its conclusions was that the Foreign Relations series had fallen into serious disarray since 1953. Prior to that time the volumes had been published with fair regularity about fifteen years behind currency (volumes for the 1920 s and early 1930s). Then, at the behest of several influential members of Congress, the Historical Office was required to push ahead 
with volumes on China (1942-1949) and on the top wartime conferences. Meanwhile the rest of the series was allowed to drop farther and farther behind currency until now it has slumped to twenty years and is losing ground every year. Further confusion was added in 1957 when the publication of the speeded-up China series was suddenly stopped by Secretary Dulles.

All this has meant loss of morale in the Historical Office, increased difficulties with clearanceand considerable unfavorable publicity for the series as a whole.

The central recommendation of our Committee is that this unhappy situation could be corrected if henceforth the Foreign Relations volumes were published in orderly fashion twenty years behind currency and if no series were undertaken out of chronological order.

We believe that a twenty-year lag behind currency is sufficient to take account of the problem of current sensitivity, particularly since the Historical Office is prepared to omit passages in documents that might really be offensive to friendly individuals or governments. Current sensitivity will also be greatly diminished by the mere fact that the volumes will again appear as a historical series in regular chronological order. The Secretary has indicated his favorable attitude toward our recommendation.

The Committee reports that Dr. William M. Franklin has now become director of the Historical Office. It believes that an excellent appointment has been made. His energy and competence impressed us all. The Committee also reports the addition to the staff of Dr. S. Everett Gleason, whose high abilities are known to all students of American foreign policy.

Under the new setup work has gone forward in trckling the problems presented in connection with the 1945 and 1946 volumes, and in selecting materials from the massive documentation for those years, so that the number of volumes per year can be held to a reasonable figure while keeping the quality high. Even with these improvements in procedure, the Historical Office will need some additional staff to cope with the tremendous documentation of the postwar years. The Committee has repeated its recommendation that two or three additional positions in the Historical Office are absolutely necessary to keep the series from sliding indefinitely backwards.

The Committee will explore with Dr. Franklin a suggestion for academic interns in the Historical Office. We believe that this would have certain real advantages, but it would not lessen the immediate need for adding two or three regular positions to the staff.

Finally, the Committee desires to express its appreciation of the devoted and competent services of Dr. G. Bernard Noble who has now re- tired; and to pay tribute to Gustave A. Nuermberger whose death deprives the Office of a much valued member.

November 19, 1962

Dexter Perkins, Chairman
Fred H. Harrington
Richard W. Leopold
Cluance A. Berdaht
Leland M. Goodrich
Philip W. Thayer
Robert R. Wilson

Representing American Historical Association:

Dexter Perkins, Mellon Professor of History, University of Pittsburgh

Fred H. Harrington, President, University of Wisconsin

Richard W. Leopold, Professor of History, Northwestern University

Representing American Political Science Association:

Clarence A. Berdahl, Professor of Political Science, emeritus, University of Illinois; Visiting Professor of Government, Southern Illinois University

Leland M. Goodrich, Professor of International Organization, Columbia University

\section{Representing American Society of International Law:}

Philip W. Thayer, Professor of International Law, School of Advanced International Studies, Johns Hopkins University (in Washington)

Robert R. Wilson, Professor of Political Science, Duke University

Excerpt from a letter of December 29, 1962, from Secretary of Statc Dean Rusk to Professor Perkins:

... I have now had the opportunity to read this report with some care, and I should like to thank you and the other members of the Committee for the time and thought that you have generously given to the problem.

I think your recommendations that these volumes be published in regular chronological order and be kept within twenty years of currency are reasonable, and I shall so inform our Historical Office. You will understand, however, that publication of a volume may occasionally be delayed because of the current sensitivity of significant documents. I trust that such instances will be rare and that we can hold to a twenty-year line with fair regularity.

Sincerely yours,

/s/ Dean Rusk 